\title{
Meaning Relations in the Headlines of 'Analisa' Daily Newspaper
}

\author{
Salliyanti $^{1 *}$, Isma Tantawi ${ }^{1}$ \\ Faculty of Cultural Sciences, University of Sumatera Utara \\ *Corresponding Author: Salliyanti, Faculty of Cultural Studies, University of Sumatera Utara
}

\begin{abstract}
This study aims to determine the type of meaning and relationship of meaning in the headlines of Analisa Daily Newspaper in Medan. The theory uses the structural semantics that is based to the opinion of Chaer. ${ }^{1}$ The method used to analyze the data is a method of matching which means the outside device is not part of the language. In this case the basic technique involves the technique of decisive elements. Moreover, qualitative descriptive method is used. This means that this last method as a whole takes advantage of the ways in which interpretation presents in the form of descriptions. Understanding object interpretation is done to get the best level of objectivity. In the social sciences the data source is the sentences. The result of this research shows that the types of meanings in the headlines concern with lexical, grammatical, denotational, and connotative meanings, and with meaning relationships, namely synonyms, antonyms, polysemy, and ambiquities.
\end{abstract}

Keywords: description, types, meaning relation, headlines

\section{INTRODUCTION}

One of the language activities is aimed at conveying messages or communication as shown in newspapers which consist of language symbols and meanings readers should understand. The language symbols may appear in the forms of words, phrases, or sentences. ${ }^{2}$ The meaning of words, phrases, or sentences actually become what readers try to grasp from newspapers.

Headlines are an inseparable part of newspapers. If viewed from the practical side in receiving information, the most important thing is to understand the meaning contained in the headlines because the core purpose of information submitted through the newspaper lies in them.

Newspapers transform very important information for the public. Every day people read newspapers to find out hot messages that become their focuses. Without newspapers, people are not getting the today's news, knowledge, as well as incidents. Especially, at this time, many good or bad news concerning law, economy, corruption and terrorism might bring negative impacts on readers. Thus, without newspapers, the public will become blind to the news or events that have occurred.

If we look at a newspaper, for example, the first thing to see is its headline which can become readers' interests or not. If news is dealt directly with our problem then we read the whole news. If what we are looking is found, we become uninterested in the news and we then read the headlines.

In this occasion, the researcher discusses the type of meaning and the relation of meaning of headlines of Analisa daily newspaper. The core of the information conveyed through the newspaper lies in its head. So, it is necessary to understand its meaning. ${ }^{3}$ It often happens after reading the headlines readers mistakenly respond because the content of the headlines does not match the message. What is targeted in this research is the type of meaning and the relation meaning.

\section{LITERARY REVIEWS}

The word 'semantics' is actually a technical term that refers to the study of meaning. This semantic term emerged and introduced through the American Philological Association of 1894 Goseriu and Gecheler (1981). Pateda ${ }^{4}$ states that the semantic term that became popular in the fifties was first introduced by a French scholar named Breal in 1883. Semantics as a discipline appeared in the 19th century. 
Semantics becomes the study of meaning and the meaning implied in the sentence is also targetted as the object of discussion in semantics, and the meaning that arises in the discussion of a word is called word meaning. ${ }^{5}$ Discussing about the word meaning becomes a semantic object so it is a vast field of study of meaning. ${ }^{6}$ Experts argue semantics is the study of meaning. According to them the semantics assume the language consists of structures that manifest meaning when connected with objects in the experience of the human world.

According to Pateda (see [1]) empirically before one speaks and when one hears a person's utterance there is a mental process in both of them. The mental process is a process of composing semantic code, grammatical code and phonological code on the part of the speaker, and the process of decoding phonological, grammatical, and semantic codes fall on listeners. In other words, both speaker and on listener undergo meaning process and involve in the code interpretation. Then semantics is a linguistic subdiscipline that is oriented to meaning or objectivity.

\section{RESEARCH METHODS}

The method used in the data collection is the recording technique and data analysis method involves the method of matching meaning that the outside device is not part of the language. In this case the basic technique uses the technique of decisive elements and in the following, qualitative descriptive method is used. ${ }^{7}$ This means that this qualitative method of analysis as a whole takes advantage of the ways in which interpretation presents in the form of descriptions. Understanding object interpretation is done to get the best level of objectivity. In the social sciences the data source is the language ie sentences. The instrument which helps the interpretation is based on Kamus Besar Bahasa Indonesia $1988 .^{8}$

\section{RESULTS AND DISCUSSION}

\subsection{Lexical Meaning}

Data 1. Ibadah Khusus Bulan Ramadan (Analisa, June 2, 2017: 26)

'Special worship of Ramadhan'

The words in Data 1 have lexical meanings which are in accordance with the dictionary. The word ibadah lexically means 'the act of declaring devotion to God' (KBBI, 1988: 319). The word khusus lexically means 'unusual, distinctive, special' (KBBI 1988: 437). The word bulan means 'celestial bodies around the earth in one month' (KBBI 1988: 134). The word ramadan literally means 'the ninth month' or 'the fasting month' according to the year of Hijrah (KBBI, 1988: 723).

Data 2. Harga Beras Mulai Stabil (Analisa, April 27, 2017: 21)

'Rice price begins to be stable'

The words in data 2 are all categorized to have lexical meanings since they are in accordance with the dictionary. The word harga means 'the value or price of goods specified or comparatively determined with money' (KBBI, 1988: 297). The word beras lexically means 'peeled rice' (KBBI, 1988: 106). The word mulai lexically means 'to start doing or to act' (KBBI, 1988: 597). The word stabil is lexically means 'stable, fixed, unchangeable'.

Data 3. Delapan Benda Pusaka Museum Raib (Analisa, 22 Maret 2017: 1)

'Eight relics in the museum disappeared'

The words in Data 3 also have lexical meanings which are easily based on the dictionary. The word delapan lexically means 'the name addressed to symbol of number' or 'eight' (KBBI, 1988: 193). The word benda lexically means 'everything that exists in the tangible realm' (KBBI 1988: 100). The word pusaka lexically means 'the possessions of the dead' (KBBI 1988: 21) and benda pusaka means 'relics'. The word museum lexically means 'the building used as a venue for exhibitions' or 'museum' (KBBI 1988: 601). The word raib means 'magically disappears' or 'lost' (KBBI 1988: 721).

\subsection{Gramatical Meaning}

Data 4. Isu Penculikan Anak Resahkan Masyarakat (Analisa, Maret 22, 2017)

'Issues of child abduction worried people' 
The word penculikan 'abduction' or 'kidnapping' has grammatical meaning which is formed from the base culik 'to kidnap' that lexically means 'to take with certain intentions (KBBI 1988: 176). The word penculik 'kidnapper' gets the affix -an that forms a noun. The word meresahkan or resahkan 'to worry' has also a grammatical meaning 'to make it uneasy' (KBBI 1988: 744). The word is formed from an uncomfortable base that gets a suffix to be restrained.

Data 5. Penjual Ganja Dituntut 10 tahun Penjara (March 24: 6)

'Marijuana seller prosecuted for 10 years in prison'

The word penjual 'seller' which has the grammatical meaning is formed from the basic word of jual 'to sell' which lexically means 'transferring property' (KBBI 1988: 366). The word jual gets affix pe$\mathrm{N}$ that becomes penjual 'the seller' then its meaning becomes grammatical meaning that is 'people who sell' (KBBI, 1988: 366). The word dituntut has also grammatical meaning and is formed from the basic word tuntut which lexically means 'to charge' or 'to ask vigorously (half requires that it be fulfilled' (KBBI 1988: 975). The word dituntut is claimed to be a derivative word that becomes a passive word and has the grammatical meaning 'to be punished'.

\subsection{Denotational Meaning}

Data 6. Elpiji 3 Kg Langka Di Subulussalam

'LPG of $3 \mathrm{Kg}$ is rare in Subulussalam'

All the words in this headline are a series of words having denotative meanings because they do not change the basic meanings. The word elpiji means 'liquid petroleum gas' (KBBI 1988: 225). The word tiga means 'the name of the number for the symbol of the original number' or 'three'. The $K g$ is the short form of kilogram meaning 'unit of weight' (KBBI 1988: 441). The word langka means 'rarely obtained' or 'rarely found' (KBBI 1988: 4980). The phrase di Subulussalam is the name of a district in Dairi regency. So, the headline contains connotative meaning because it is reinforced with the word langka which is in accordance with the true meaning.

Data 7. Tidak Ada Lagi Kerahasiaan Data Nasabah (Analisa, March 25, 2017: 17)

'No nore confidentiality of customer's data'

The words in the headlines above are a series of words that mean denotation. The series of words do not change the meaning of the basic meaning. The word tidak ada means 'particle' expressing rejection or denial. The word kerahasiaan means 'secrecy' or 'confidentiality' (KBBI 1988: 726). The word data means 'true and correct information'. The word nasabah means 'a person who makes a deal with the bank.' So the headline above is a denotation because it is reinforced by the words data and kerahasiaan that match with the real and objective meaning.

\subsection{Connotative Meaning}

Data 8. Soal USBN Bocor, Hoax (Analisa, March 23, 2017: 1)

'USBN examination leak, a hoax'

In the headline above the word bocor carries connotative meaning which is influenced by subjective, but not objective, values. The word bocor is sometimes connected with the word bucket or tyre. For example, the bucket is leak or the tyre of my bicycle is leak. So, the headline above has a connotative meaning because it is reinforced by the word bocor whose meaning 'is not perfectly known'.

Data 9. 23.270 Siswa di Sumut Putus Sekolah (Analisa, Maret 23, 2017: 12)

'23,270 students in North Sumatra dropout'

In the headline above the word putus sekolah 'dropout' has connotative meaning and is influenced by subjective, but not objective, values. The word putus literally means 'being cut' or 'broken into pieces'. So, the headline above is categorized as connotation because it is reinforced with putus sekolah which can be translated into 'no longer connected' in English.

Data 10. Lima Puluh Enam Rumah Tidak Layak Huni Dibedah (Analisa, October 18, 2017: 12) 
'56 houses not eligible, disposed'

In the headline above the word dibedah 'being dissected/operated' contains connotative meaning and it is influenced by subjective, but not objective, values. The word dibedah is a passive word and literally means 'disease treatment by cutting off the sick body part' (KBBI 1988: 91) so it brings denotative meaning. Thus, the headline above has a connotation meaning because it is reinforced by a dissected word whose connotation meaning is 'repaired or renewed'.

Data 11. KPK Tetapkan Irjen Kemendes Tersangka Suap (Analisa, May 28, 2017: 1)

'KPK sets Inspector General of Kemendes bribe suspects'

In the headline above there is one word having connotative meaning, namely, the word suap 'bribe' which is influenced by subjective values but not objective. The word suap literally means 'rice picked up with the finger and put into the mouth when eating' (KBBI 1988: 861). This means denotation so the headline above has a connotation because it is reinforced by the word suap whose connotative meaning is 'to ask for money'.

\subsection{Meaning Relations}

\subsubsection{Synonym}

Data12. Bus Tabrak Truk, DuaTewas (Analisa, October 10, 2016: 1)

'Bus crashed truck, two killed'

The word tewas 'died or killed' in the headline has two synonymous forms in English meaning 'no more life'; however, this word has five synonymous words, for example, mati, meninggal, etc. in Bahasa Indonesia which can not be used into one sentence because they must be precise and common. So even though the words tewas and meninggal are synonymous but the most precise word for the sentence above is the word meninggal which is used for person. This synonymity is not absolute or does not have exactly the same meaning.

Data 13. Lonjakan Harga Dirasakan Masyarakat Penghasilan Rendah (Analisa, 20 October 20, 2016: 21)

'Price increase felt by low income society'

The word rendah 'low' in the headline has several English synonyms, for instance, 'disgrace, contempt, small, cheap, short, succinct, meaningless, not high, near down, and feeling inadequate'. Although those words are synonymous but we can not put them into one sentence. Such words should be appropriate and prevalent. The word rendah 'low' can not be replaced with a short, humble, disgraceful word on the headline above, inappropriate, and unorthodox. Synonymity is not absolute.

\subsubsection{Antonym}

Data 14. Nasabah Sidikalang Menang Undian Simpedes (Analisa, March 27, 2017: 21)

'Customers from Sidikalang won Simpedes lottery'

The word menang 'to win' in the headline of the news above has the form of antonyms with the word kalah 'to be defeated or to loose' because there is an absolute contradiction of meaning. So, menang and kalah are antonymous which are in absolute opposition. Between these words there is an absolute limit because someone who won certainly not lost, otherwise the loser certainly did not win.

Data 15. Kepala Daerah Harus Aktif Awasi Warga (Analisa, October 10, 2016: 5)

'Heads of regions must be active to watch inhabitants'

The word aktif 'active' in the above sentence is anonymous with the word pasif 'passive' because there is an absolute contradiction of meaning. Thus, the aktif and pasif words are the antonymous in their absolute opposition. Between these words there is an absolute limit of words, because something that is active is certainly not passive, otherwise something passive is certainly not active.

\subsubsection{Polysemi}

Data 16. Mantan Kepala Dinas PU Sergai Mangkir (Analisa, March 22, 2017: 6) 
'Former Head Office of Sergai Public Works absent'

The word kepala 'head' in the headline of the Analisa newspaper above is a form of polysemic because it has more than one meanings and means 'leader or chairman'. Meanwhile, this word in accordance with the Indonesian dictionary means 'body part from the neck up that is found in humans and animals', for example, his head hits rock. Moreover, the kepala kerata api 'head of the train 'means 'the front important part of train or locomotive'. The kepala kodi means 'the cloth that is placed on top of the fabric bond'.

Data 17. Harga Daging Naik Tajam (Analisa, May 20, 2017: 1)

'Meat prices rise sharply'

The word tajam literally 'sharp' in the headline of the news above is a form of polysemic because it has double meanings and means a 'drastic increase'. This word in the Indonesian dictionary is translated into English as 'thin-eyed, smooth,easy slice, or injure' (those meanings are related to knife or sword). There is a compound word, such as, tajam mulut which literally means 'sharp mouth'. Someone who has tajam mulut is indicated by the use of his words which attacks heart.

\subsubsection{Ambiguity}

Data 18. Berikan Data Valid Calon Komisioner OJK (Analisa, May 20, 2017: 5)

'Give valid data about OJK commissioner candidates'

The headline above has ambiguous meanings because it can be interpreted as (1) giving valid data and (2) candidates of OJK commissioner. So, the headline above is not clear or ambiguous. If the headline above becomes Calon komisioner OJK memberikan data valid "OJK commissioner candidate gives valid data" then the coercion/ambiquity is not found.

Data 19. Gubernur : Hukum Berat Pembunuh Istri Hamil (Analisa, March 20, 2017: 1)

'Governor: Sentence heavily the killer of pregnant wife'

The headline above is ambiguous because it can be interpreted as (1) the killer killed his pregnant wife and (2) he killed somebody's wife who was pregnant. If the headline is modified into Gubernur: pembunuh isteri hamil dihukum berat 'Governor: the killer of pregnant woman is sentenced heavily', then the coercion is not available.

Data 20. Luas Tambah Taman Maret Meningkat (Analisa, March 7, 2017: 25)

'Width-augment areas of Taman Maret increase'

The headline above has ambiguous meaning because there is no clear punctuation. So, it can be interpreted ambiguously: (1) width-augment areas of parks is increased in March meaning the park areas are added, and (2) width-augment areas of Taman Maret increase meaning the Taman Maret is continuously increased. Then there is a coercion. If the headline above has comma, for instance, penambahan luas taman, meningkat pada Maret 'additional areas of park, incresed in March', then there will be no coercion.

\section{CONCLusions}

Based on the results of data analysis, it can be concluded:

a. In the headlines of the Analisa it is found kinds of meanings in the lexical, grammatical, denotative, and connotative meanings.

b. The relations of meaning in the Analisa are found in the form of synonyms, antonyms, polysemics, and ambiquity. The relationship of meaning in relation to ambiquity is very influential on the contents because it does not use both punctuation and information provided; as a result, the readers become confused with the headlines because they have double meanings.

\section{REFERENCES}

Aminuddin, 200 1. Pengantar Studi Tentang Makna. Bandung: Sinar Baru.

[1] Chaer, Abdul. 1995. Pengantar Semantik Bahasa Indonesia. Jakarta: Rineka Cipta.

[2] Sibarani, Robert. 1992. Hakikat Bahasa. Bandung: Citra Aditya Bakti. 
[3] Gultom, Lelly. 2010. Deskripsi Semantik Kepala Berita di Harian Metro Tapanuli. Medan : USU Press.

[4] Pateda, M. 1996. Semantik Leksikal. Flores NTT : Nusa Indah.

[5] Leech, Geoffrey. 2003. Semantik. Pama Panama. Yogyakarta: Pustaka Pelajar.

[6] Parera, Jos Daniel. 1991. Teori Semantik. Jakarta: Erlangga.

[7] Sudaryanto. 1993. Metode dan Aneka Teknik Analisis Data. Yogyakarta: Duta Wacana University Press.

[8] Departemen Pendidikan dan Kebudayaan. 1988. Kamus Besar Bahasa Indonesia. Jakarta: Balai Pustaka.

Citation: Salliyanti \& Isma Tantawi " Meaning Relations in the Headlines of "Analisa' Daily Newspaper". International Journal of Humanities Social Sciences and Education (IJHSSE), vol 4, no. 11, 2017, pp. 92-97. doi: http://dx.doi.org/10.20431/2349-0381.0411011.

Copyright: (c) 2017 Authors. This is an open-access article distributed under the terms of the Creative Commons Attribution License, which permits unrestricted use, distribution, and reproduction in any medium, provided the original author and source are credited. 